\title{
POSTNATAL MATURATION OF CEREBELLAR MOSSY AND CLIMBING FIBERS: TRANSIENT EXPRESSION OF DUAL FEATURES ON SINGLE AXONS ${ }^{1}$
}

\author{
CAROL ANN MASON ${ }^{2}$ AND ELIZABETH GREGORY
}

Department of Pharmacology, New York University School of Medicine, New York, New York 10016

Received September 26, 1983; Revised January 9, 1984; Accepted January 10, 1984

\begin{abstract}
We have studied the form and fine structure of developing afferent axons in postnatal mouse cerebellum, before and during the formation of synaptic connections. In slices of fresh brain, bundles of axons were injected with horseradish peroxidase (HRP), and individual axons were examined in the light and electron microscopes. At birth, before formation of cortical layers, axons with growing tips are rare in the peduncular tracts but instead ramify throughout the cerebellar anlage. All axons have similar structures; they branch infrequently and terminate in bud-like tips and/or small growth cones. Growth cones contain small and large vesicles in the flank and small vesicles in filopodia.

Typical mossy and climbing fiber branching patterns and bouton shapes are recognizable after postnatal day (P) 5, even though fibers are still intermingled in a plexus beneath the newly formed Purkinje cell layer. Climbing fiber-like axon arbors are highly branched and covered with small foliate growing tips that contact Purkinje cells. Mossy fiber-like branches have large irregular expansions that give rise to long filopodia and resemble growth cones seen in vitro. The flanks of these growth cones contact granule cell dendrites and form glomeruli typical of mossy fibers, whereas the filopodia make primitive contacts or are associated with coated vesicles in adjacent profiles. A novel finding is the occurrence during the second postnatal week of many single axons that simultaneously have the morphology and synaptic connections of both climbing and mossy fibers. These "combination" axons have some branches that extend into the granule cell layer and others that enter the Purkinje cell layer, with the shape and synaptic connections of terminals on each branch type corresponding to the respective layer. Climbing fiber-like branches, including those on combination fibers, extend over several adjacent Purkinje cells. Combination fibers are rare in late postnatal or adult stages.

These results suggest that long after arrival in the cerebellum, afferent axons have similar elementary forms and overlap in their projections. Mature axonal forms are not exhibited until cellular layers develop. During a limited period of postnatal maturation, some axons have dual morphologies and synaptic relations with appropriate and inappropriate partners. These aspects of cerebellar axonal development, particularly the transient exuberant branching onto two types of target cells, offer a valuable opportunity to examine, in developing cerebellum, the sorting out of afferents and the formation of specific synaptic connections.
\end{abstract}

The means by which axons make synaptic connections is a central question in neuronal development. We currently understand little about the forms of growing tips in vivo once axons reach target areas, or the significance

\footnotetext{
${ }^{1}$ We thank Drs. M. E. Hatten, R. Llinás, and M. D. Shaw, and M. L. Shelanski for their useful comments, Dr. H. Jahnsen for his advice on the slice preparation, and Yvel Calderon and Julia Cohen for preparing the manuscript. Supported by National Institutes of Health Grant NS-16951. C. A. M. is the recipient of a Research Career Development Award (NS00639) and an Irma T. Hirschl Career Scientist Award.

${ }^{2}$ To whom correspondence should be addressed.
}

of these forms during interactions among different target cell types, as single growth cones transform into synaptic arbors.

The behavior of growing axons has been primarily studied in vitro (for review, Letourneau, 1982). Living axons have been directly observed in amphibian systems (Harrison, 1910; Speidel, 1942). Axon outgrowth and pathfinding are being documented in identified cells in the insect nervous system (Keshishian and Bentley, 1983; Raper et al., 1983), but few studies of this sort have been carried out on the mammalian CNS.

To examine more closely some fundamental aspects of 
axonal development in the mammalian CNS, we have turned to the developing cerebellum. The repetitive cellular and synaptic organization of both adult and developing cerebellum make it the most well understood region of the CNS (Ramón y Cajal, 1911, 1960; Palay and Chan-Palay, 1974; Rakic, 1975). The major afferent axons, climbing and mossy fibers, interact with different target cell types in distinct layers and have characteristic features in the adult animal. Ramón y Cajal (1911, 1960) continually invoked the early stages of climbing fiberPurkinje cell dendrite association as a prime example of neurotropism. The development of the climbing fiber arbor in relation to Purkinje cell dendritic outgrowth has been delineated in Golgi preparations (Ramón y Cajal, 1960; O'Leary et al., 1971; Palay and Chan-Palay, 1974), and synaptogenesis of several components of the cerebellum has been described in detail (Larramendi, 1969; Mugnaini, 1969; Altman, 1972; Hámori and Somogyi, 1983; Landis et al., 1983). Electrophysiological studies have shown that unlike adult cells, immature Purkinje cells receive input from more than one climbing fiber (Crepel et al., 1976; Mariani and Changeux, 1981; Crepel, 1982), indicating that like several other axonal systems (for review, Purves and Lichtman, 1980; Clarke, 1981), climbing fibers at first develop supernumerary branches which are subsequently eliminated in late posnatal periods.

Although the Golgi methods have provided much of the existing information on axonal development in vertebrate systems (e.g., Ramón y Cajal, 1960; Morest, 1968; Amaral and Dent, 1981; Jhaveri and Morest, 1982), the methods more frequently yield impregnation of perikarya and dendrites and do not allow preselection of which axons will stain. In contrast, injection of dyes, such as horseradish peroxidase (HRP), permits choice of elements to be labeled and provides an equally detailed view of axonal and dendritic features. Because HRP is electron-dense, identified structures can be studied in the electron microscope and forms of growing tips related to their cytology. We have previously used this method of HRP labeling to resolve branching patterns, terminal shapes, and synaptic relations of individual adult and immature axons in intact mammalian CNS in the cat retinogeniculate system (Mason and Robson, 1979; Robson and Mason, 1979; Mason, 1982a, b).

With the same HRP labeling technique, we have examined several features of afferent cerebellar axons during postnatal maturation, after axons have arrived in the cerebellar anlage. In this first report, we describe the onset of expression of characteristic features of mossy and climbing fibers, with respect to branching patterns and synaptic boutons. We were interested in determining whether the growing tips of immature axons that have recently reached target areas reflect their future phenotype, and whether the characteristic branching pattern and terminal form develop in a straightforward manner, without confusion of identity or overlap in projections. We also provide preliminary data on the cytology and synaptic relations of early growing tips and growth cones, especially during the transition from growth cone to mature synaptic terminal. In addition, we report the first use of brain slices as a preparation for axon labeling.
Axon bundles were visualized in the slice, injected with HRP, and subsequently analyzed in both the light and electron microscopes.

\section{Materials and Methods}

All experiments were carried out with $\mathrm{C} 57 \mathrm{BL} / 6 \mathrm{~J}$ mice derived from a timed-pregnancy breeding colony in this department. Apart from some older animals at postnatal day (P) 30 and adult animals, injections of axons with HRP were made directly into isolated slices of fresh cerebellum, kept in tissue culture medium at $37^{\circ} \mathrm{C}$. Animals from P0 to P21 were anesthetized with Nembutal, decapitated, and the brain removed to filter paper moistened with tissue culture medium. Slices 500 to $700 \mu \mathrm{m}$ thick were made with a razor blade and placed in a Petri dish filled with tissue culture medium consisting of Eagle's Basal Medium with Hanks' salts, glucose ( $8 \mathrm{~mm}$ ), glutamine $(4 \mathrm{mM})$, and penicillin/streptomycin $(20 \mu \mathrm{l} /$ $\mathrm{ml})$. The preparation was illuminated from below and was kept at $37^{\circ} \mathrm{C}$ by means of an air curtain incubator (Arenberg Sage).

After a brief equilibration period (up to $30 \mathrm{~min}$ ), axon bundles were filled with HRP (Sigma, type VI). A glass micropipettc with a 10 - to $20-\mu \mathrm{m}$ tip was coated with a concentrated solution of HRP and allowed to dry. The tip was inserted into the inferior or middle cerebellar peduncle or into white matter tracts. After an additional $15 \mathrm{~min}$ the slices were then fixed by immersion in $1 \%$ paraformaldehyde $/ 1 \%$ glutaraldehyde in $0.1 \mathrm{M}$ phosphate buffer, $\mathrm{pH} 7.3$.

Older mice were anesthetized with Nembutal and inserted into a Kopf stereotaxic frame. The skin was incised, and a small hole was drilled in the skull. A glass micropipette was inserted into the cerebellum, and a small amount of concentrated HRP solution (0.01 to 0.05 $\mu \mathrm{l})$ was injected by pressure into the cerebellar white matter. Animals were allowed to rest for 4 to $6 \mathrm{hr}$ and were perfused with the same fixative as above.

Both slices and dissected whole brain were stored in fixative overnight at $4^{\circ} \mathrm{C}$ and were then embedded in gelatin-albumin hardened with glutaraldehyde. Parasagittal sections were cut at $75 \mu \mathrm{m}$ on a vibratome (Oxford) and were placed in phosphate buffer. They were reacted in diaminobenzidene in phosphate buffer and hydrogen peroxide, without cobalt treatment. All sections were then prepared for electron microscopy by rinsing them in buffer, followed by osmication, en bloc staining with uranyl magnesium acetate, dehydration in ethanols, and embedding in Epok (Fullam). Sections were embedded between two plastic slides.

After polymerization, the thin plastic wafer was separated from the slides and placed on a glass slide. Axons were then examined in the light microscope and drawn with the aid of a Leitz drawing tube and $\times 100$ oil immersion objective. Pieces of the wafer were glued to Fpon stubs and sectioned with a glass knife at $7 \mu \mathrm{m}$. These sections were placed on a glass slide, and sections containing pieces of the original arbor were drawn at the same magnification as well as photographed with phase contrast optics. By placing the drawing of the $7-\mu \mathrm{m}$ sections on the original drawing, pieces of the axon of interest became evident. The selected $7-\mu \mathrm{m}$ sections were 
removed from slides and remounted onto a faced-off block.

Thin sections were cut and placed on single-holed Formvar-coated grids, stained with uranyl acetate and lead citrate, and examined on a JEOL $100 \mathrm{~S}$ electron microscope. The drawings of the 75- $\mu \mathrm{m}$ and $7-\mu \mathrm{m}$ sections as well as the phase photograph served as guides for relocating specific terminals from individual lengths of axon arbors. Over 150 preparations from cerebella at $\mathrm{P} 0$ to $\mathrm{P} 14$, three at $\mathrm{P} 21$, and three adults were studied at the light microscope level, and 12 of those preparations were submitted to electron microscopic analysis.

\section{Results}

Adult axons. Figure 1 shows camera lucida drawings of typical climbing and mossy fibers from adult mouse cerebellum labeled with HRP. The branching pattern and shapes of the terminals correspond to those in the rat (Palay and Chan-Palay, 1974). Several features should be noted: (1) Adult mossy fibers never project into the Purkinje cell layer, and climbing fibers rarely give off collaterals into the granule layer. We have noted only two cases out of nearly 100 examples in which collaterals of climbing fibers end within the granule layer in a mossy fiber-like bouton (Palay and Chan-Palay, 1974). (2) Climbing fibers have highly branched arbors that follow the course of a Purkinje cell dendrite and bear small ( 1 to $2 \mu \mathrm{m}$ ) round or indented terminals that synapse with Purkinje cell dendrites on spiny branchlets. (3) Mossy fibers have larger diameters and branch less frequently than climbing fibers. Mossy fiber boutons occur en passant, at branch points as well as at the ends of branches. They are usually large (up to $20 \mu \mathrm{m}$ long) and lobulated, although thin collaterals can also bear smooth medium-sized boutons. The large terminals are the central profile in glomeruli and synapse with granule cell dendrites.

Axons from birth to postnatal day 5. During the first few postnatal days, injections of HRP into the inferior or middle cerebellar peduncle filled axons bearing small delicate growing tips within the core of the cerebellar anlage. At P0 to P1, no axons with growth cones were seen within the tracts. Many axons project so far into the cerebellar anlage that they end in the very thin molecular layer just beneath the developing external granule layer (Fig. 2). Although it was difficult to discern Purkinje cells at this time, even in cresyl violet-stained sections, many of these fibers are situated in the future position of Purkinje cells, possibly in association with them.

The argument could be made that growth cones in transit might be damaged by the slice procedure and are, therefore, not filled. However, in several cases where the putative white matter was labeled, part of the deep nuclear region was labeled, and a few fibers with large growth cones of the sort observed in vitro and in insect embryos (Raper et al., 1983) were seen leaving the cerebellum via the superior cerebellar peduncle (not shown). These most likely represent cerebellar efferents from the deep cerebellar nuclei. Furthermore, in sections of embryonic cerebellum stained with antisera to one of the neurofilament triplet proteins, we have observed that fibers are present within the cerebellar anlage as early as embryonic day 15 (C. A. Mason and R. Liem, manuscript in preparation). Taken together, these findings suggest that axons arrive in the cerebellum and wait within cerebellar tissue for their target cells to mature for several days before birth.

We examined whether during this waiting period characteristic climbing and mossy fiber characteristics were recognizable. For the first few postnatal days, presumably a week after axons had arrived in the anlage, the identity of cerebellar axons could not be determined (Figs. 2 to 4). Figures 2 and 3 show typical axons which branch infrequently as they extend several hundred microns within the anlage. Some branches bear small growth cone-like structures with filopodia, while other branches on the same axon end in long bud-like structures, similar to those seen by Speidel (1942) on resting or nonmoving branches in his studies of growing axons in the tail fin of living tadpoles. The ultrastructure of an axonal growth cone from this period is shown in Figure 3. The HRP does not obscure bundles of fine filaments in the filopodia. Although clear vesicles occur in both the flank as well as the filopodia, and the body of the growth cone associates with an unidentified profile, synapses were not seen in these or in other serial sections of this growth cone. Other such identified growing tips remain to be studied, particularly at embryonic stages, to determine whether waiting axons establish synaptic relations with target cells.

From $\mathrm{P} 2$ to $\mathrm{P} 4$, axons still do not resemble either adult mossy or climbing fibers, but some distinguishing features appear. Small foliate or bud-like expansions and short hairs occur en passant as well as at axon tips. Branches of these fibers course around perikarya, but the identity of these perikarya and the nature of contacts, if any, made by these branches is not yet known. On other axons, larger more oblong structures occur at branch points of axons (Fig. 4). These growing tips may represent climbing and mossy fiber terminals, respectively. In the absence of the full phenotypic expression of axon branching pattern and terminal shape, the only remaining criterion for their identity is the postsynaptic target. However, because Purkinje cells are just beginning to form a monolayer, the identity of the cells in association with the axons is difficult to determine.

Climbing and mossy fibers during the second postnatal week. From postnatal day 5 onward, it is possible to identify lengths of axons as mossy- or climbing fiberlike. Immature mossy fibers become apparent as axons running nearly parallel with or at an angle to the developing white matter; these fibers give rise to an en passant series of expansions with filopodia. The expansions are small and tent-shaped and after the first postnatal week begin to have a more irregular surface. By the second week some are as lobulated as adult terminals (Figs. 5 to 7). The ultrastructure of the expansions from P7 to P10 onward confirms that these mossy fibers are the central profiles in a glomerular arrangement. Even though such terminals appear immature at the light microscopic level, that is, they have the form of growth cones in vitro and bear filopodia, the central expansion is full of synaptic vesicles and makes synaptic contacts with granule cell 


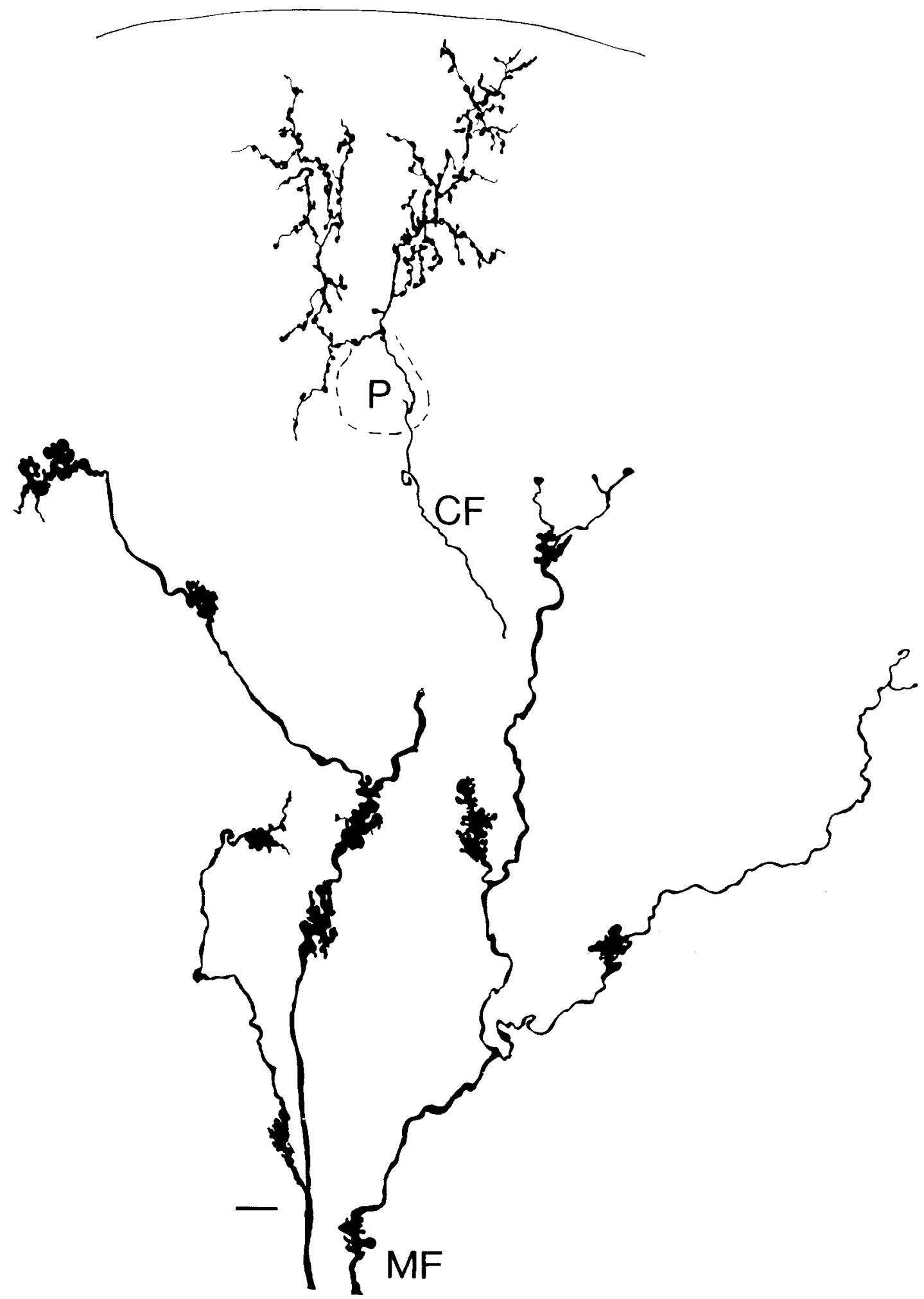

Figure 1. HRP-labeled adult climbing fiber $(C F)$ arborizing along dendrites of a Purkinje cell $(P)$ in Purkinje cell layer, and mossy fibers $(M F)$ in granule layer. These fibers were drawn to scale, but note the difference in dimensions of their respective boutons. Mossy fibers never send branches into the Purkinje cell layer, and climbing fibers rarely have mossy fiber-like collaterals. Marker $=10 \mu \mathrm{m}$.

dendrites. Such a terminal is shown in Figure 7. A section through one of the filopodia (Fig. 7,1 and $a$ ) issued by this terminal reveals a few vesicles. The profile adjacent to it contains a coated pit, commonly seen in profiles adjacent to labeled filopodia and found by others during synaptogenesis in cerebellum (Altman, 1971; Eckenhoff and Pysh, 1979). After the flank of the growing tip makes synaptic contacts, filopodia might continue to explore the surrounding neuropil in search of additional targets.

Figure 8 shows a climbing fiber-like axon that gives 


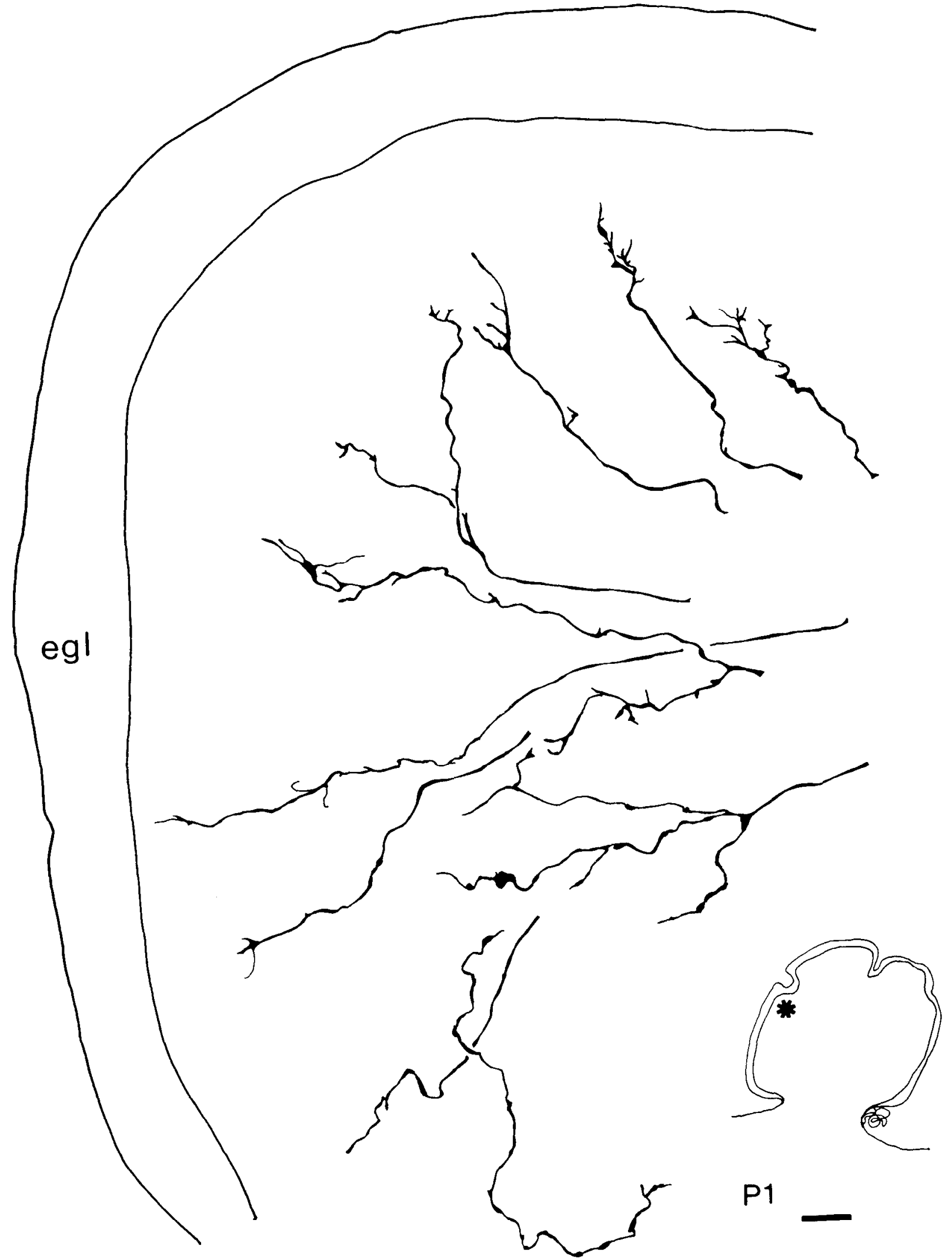

Figure 2. HRP-labeled afferent fibers in cerebellum at P1. Although foliation has just begun (see inset), these fibers extend well into the area that is the future molecular layer, and some nearly contact the external granule cell layer $(e g l)$. $M a r k e r=10$ $\mu \mathrm{m}$. 


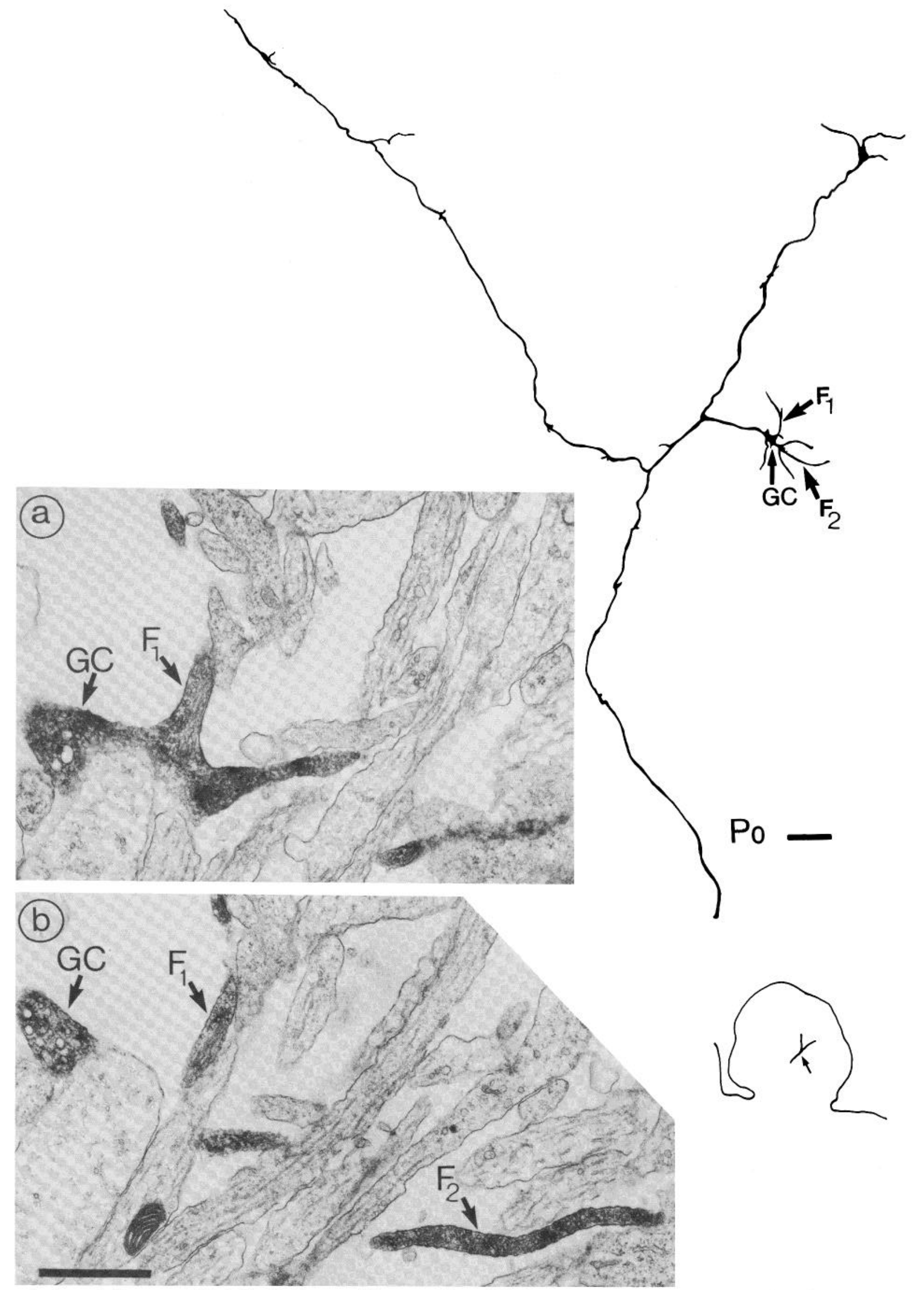

Figure 3. A cerebellar axon labeled with horseradish peroxidase (HRP) at P0. The two branches on the right end in growth cone-like structures $(G C)$ with filopodia $(F)$, whereas the left branch terminates in a slender blunt tip. Electron micrographs show serial sections through one of the growth cones $(G C)$, which contains clear vesicles of various sizes in the body of the growth cone, small vesicles and filaments in filopodium F1 and small vesicles in filopodium F2. Note the presence of small vesicles of the same size in other unlabeled profiles. No synapses were observed in these and other adjacent sections. A large amount of extracellular space is common within the cerebellar anlage at this age. Marker in drawing $=10 \mu \mathrm{m} ;$ marker in micrograph $=1 \mu \mathrm{m}$. 


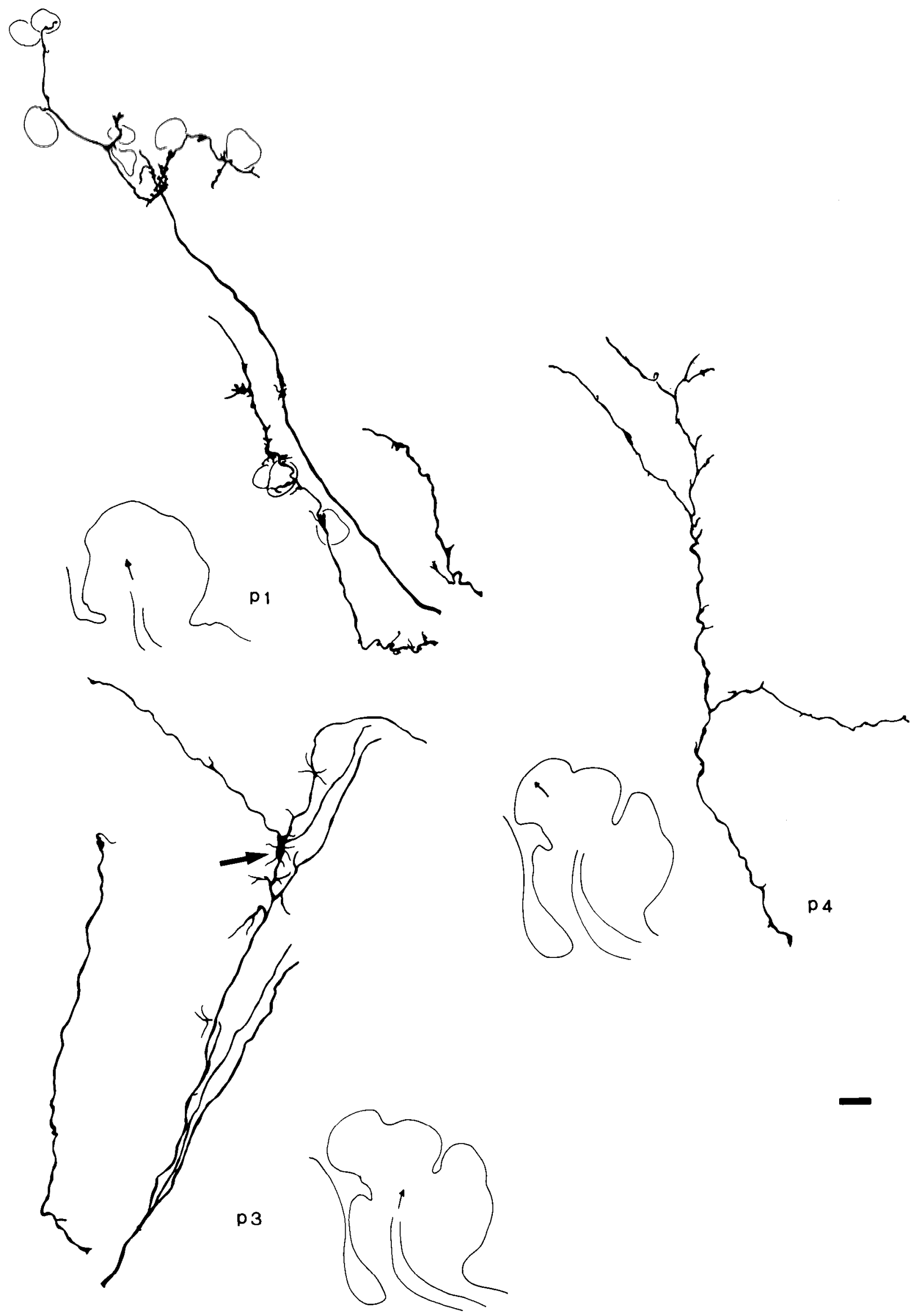

Figure 4. HRP-labeled cerebellar axons at early postnatal ages. None of these axons is recognizable as either climbing fibers or mossy fibers. An axon at P3 bears an enlarged growth cone (arrow) typical of those seen in culture. All axons, including this one, have minute foliate tips, smaller than the sorts of growth cones seen in vitro. Note filopodia on axons at P1 that course around cells (as seen in a cresyl violet-stained section). The identity of these cells is unknown, since most cells do not yet occupy their respective layers. Marker $=10 \mu \mathrm{m}$. 


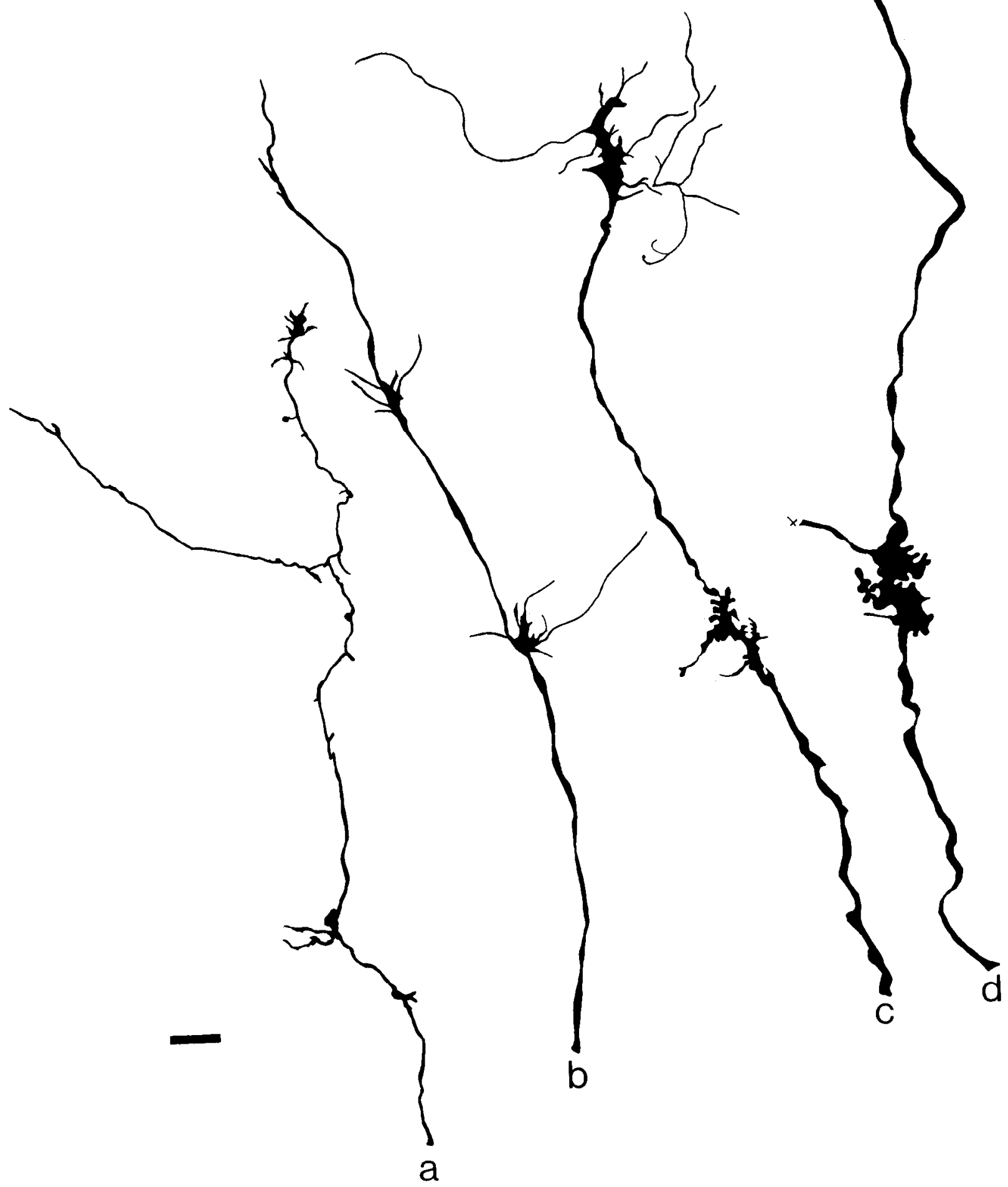

Figure 5. Immature mossy fibers, labeled with IIRP at P6 (a), $7(b), 12(c)$, and $16(d)$. At P7 (b) and 12 (c), expansions both en passant $(b)$ as well as at the ends of fibers $(c)$ resemble growth cones seen in vitro, with broad bases and long filopodia. Marker $=10 \mu \mathrm{m}$. 


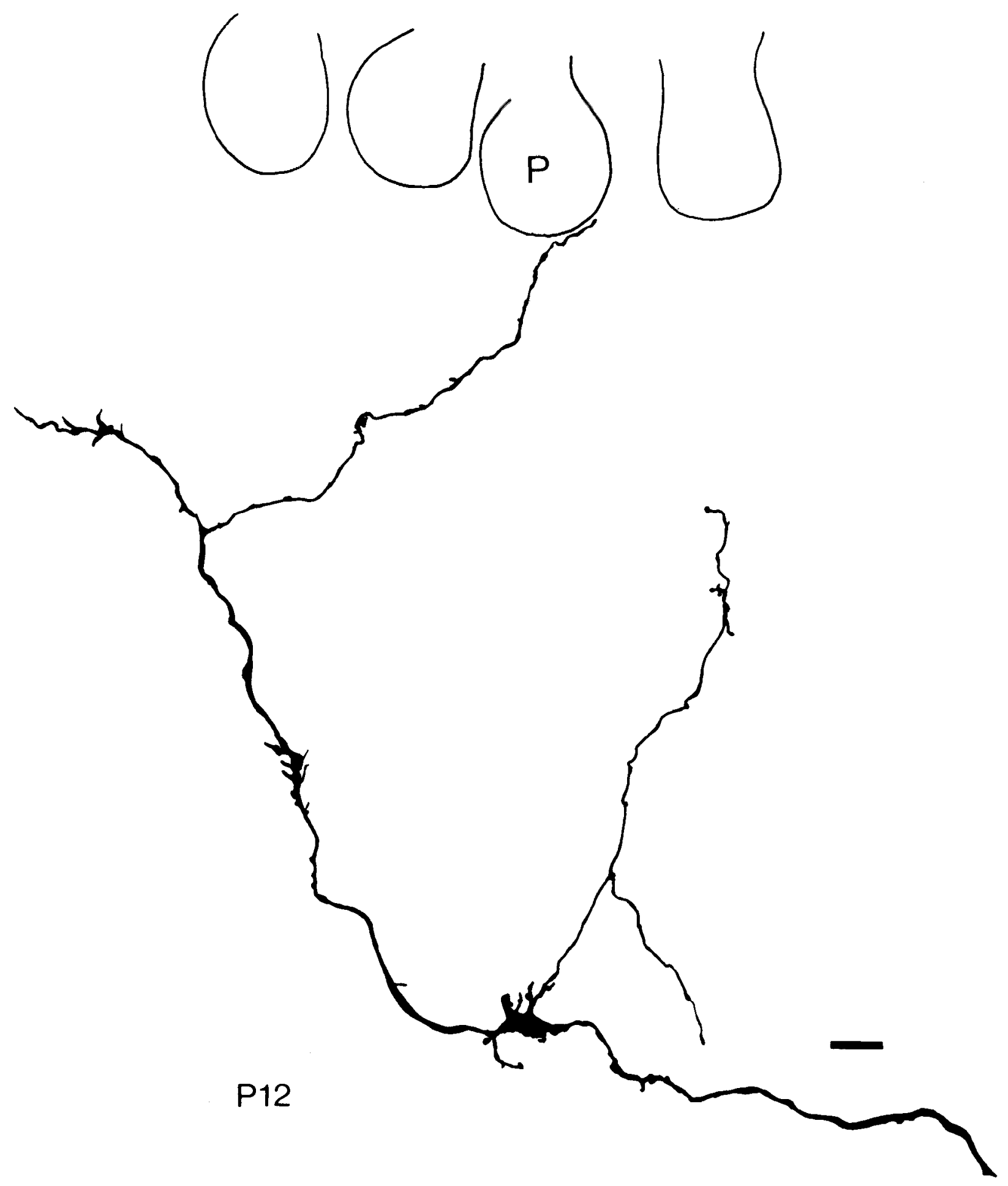

Figure 6. Mossy fiber at P12. A typical mossy swelling occurs at a branch point, whereas all three of the distal tips are immature and are not distinguishable as mossy or climbing fiber-like. The branch which approaches a Purkinje cell $(P)$ has no terminal specialization. Marker $=10 \mu \mathrm{m}$.

rise to three mini-arbors which are finely branched and relate to Purkinje cells. The small comma-shaped terminal (Fig. 8, $F, a$ to $c$ ) curves around a somatic process of the Purkinje cell nearby (Fig. 8, asterisk). The growing tip contains vesicles, but no true synaptic junction was observed. One terminal on this axon more closely resem- bles a growth cone (Fig. 8, $G$ ). This terminal was not retrieved in the ultrastructural analysis, so its synaptic relations are not known.

By P10 to P12, elementary climbing fiber branching patterns become more identifiable (Figs. 9 and 10), but the terminal boutons are not as round and smooth as in 

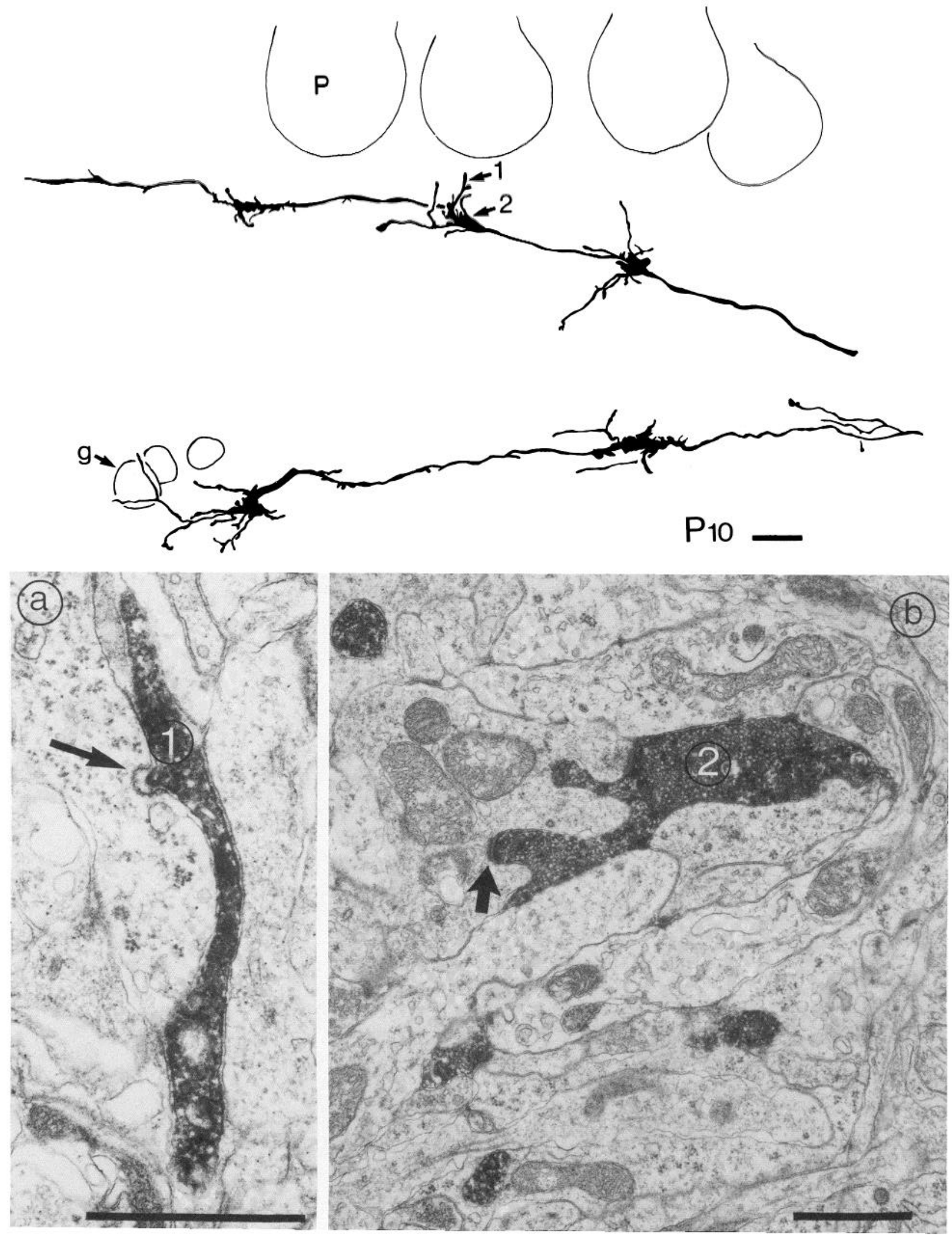

Figure 7. HRP-labeled immature mossy fibers. These large growth cone-like structures are actually immature mossy fiber terminals ( 2 on drawing and micrograph $b$ ) and form elementary glomeruli and synapse with granule cell dendrites (arrow). They also give rise to filopodia that curve around granule cells $(g)$ and often contain small clear vesicles (not shown). One filopodium (1) is apposed to a profile in which a coated vesicle is forming (arrow in micrograph $a$ ). $P$, Purkinje cell. Marker $=10 \mu \mathrm{m}$. 

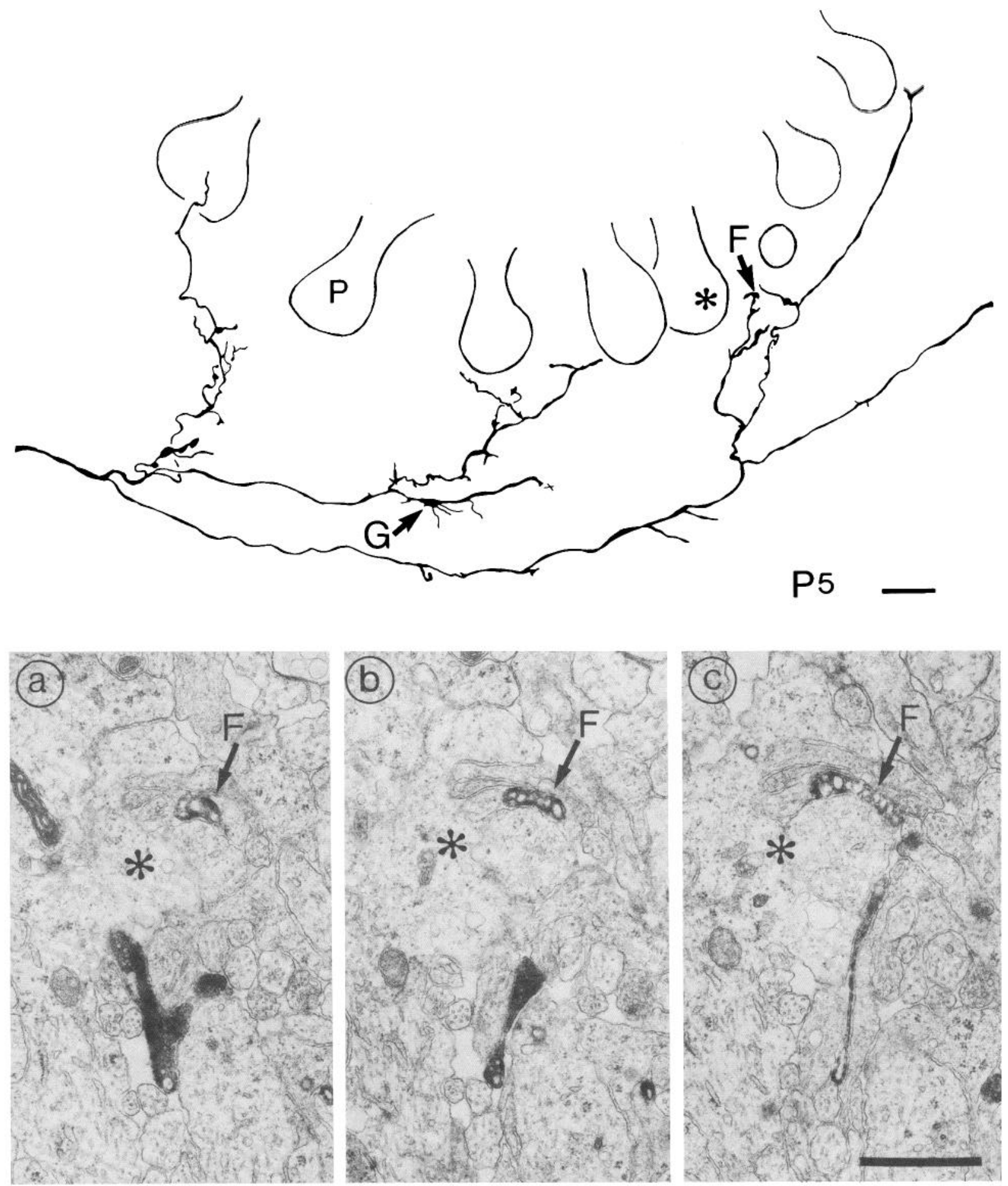

Figure 8. HRP-labeled axon at P5, considered to be an immature climbing fiber. Note that this fiber gives rise to at least three mini-arbors, one of which (to the right) bears an additional branch with blunt growing tips. However, this formation of multiple arbors occurs before the axon invades the Purkinje cell layer. One small growth tip $(F)$ was identified in thin sections as curving around a somatic process of a Purkinje cell $(P$, asterisk $)$. Although it contains vesicles, a specialized contact was not observed in these and in other serial sections. Marker in drawing $=10 \mu \mathrm{m} ;$ marker in micrograph $=1 \mu \mathrm{m}$.

the adult. Instead, short fine filopodia and foliate structures are placed along the fine climbing branches. Climbing fiber-like axon lengths are more tortuous than mossy fibers.

Fibers having both mossy and climbing fiber morphol- ogy. Although lengths of axons can be classified as mossyor climbing fiber-like with respect to branching pattern and form of terminal bouton during the second postnatal week, many axons simultaneously display characteristics of both types of afferent (Figs. 11 to 13) and, therefore, 


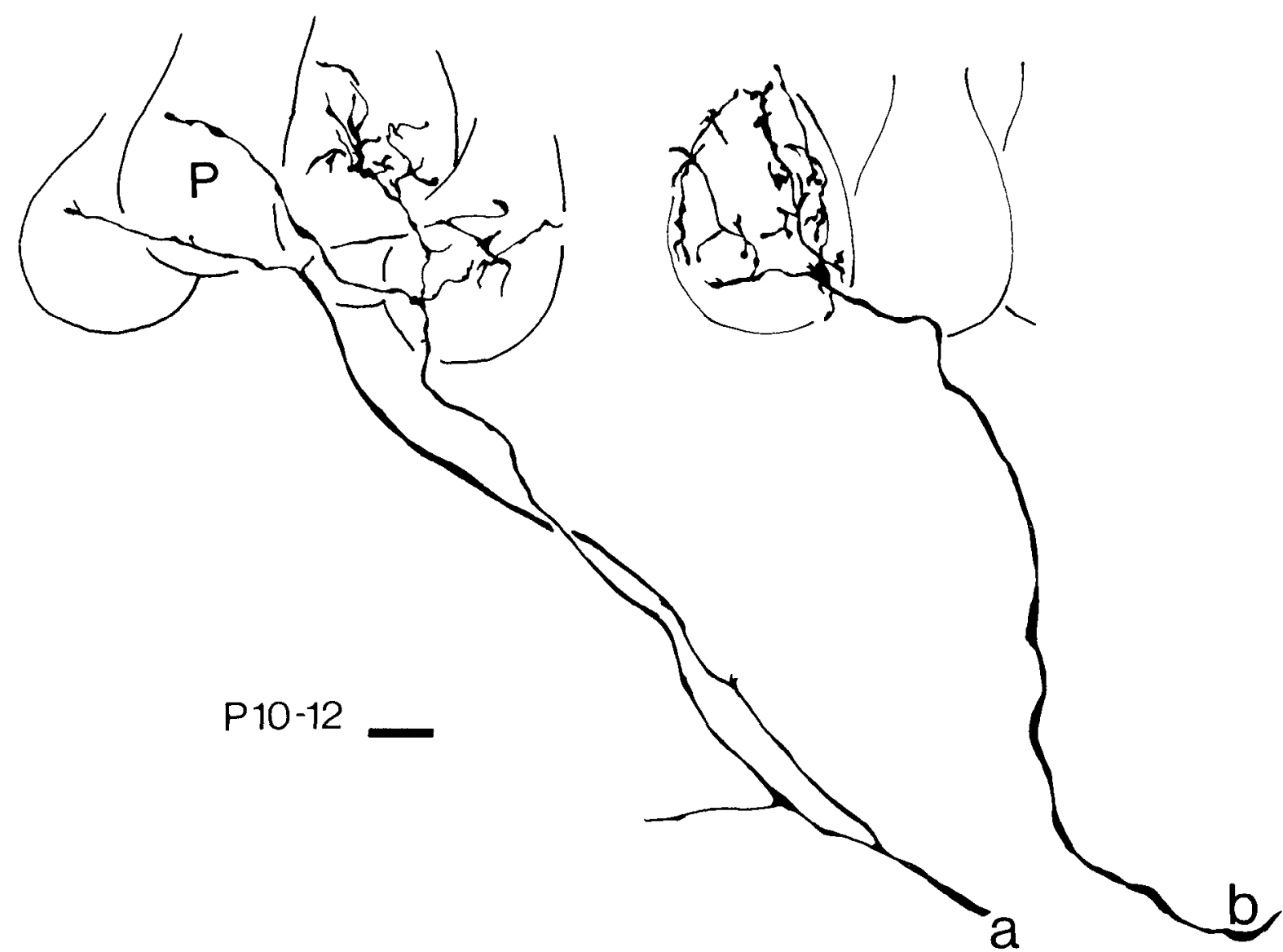

Figure 9. Climbing fibers at P10 to P12. Although from animals of similar age, these fibers are at various stages of maturation. Axon $a$ branches close to the white matter and the terminal arbors of two branches extend over four adjacent Purkinje cells $(P)$. On axon $b$, an effluorescence of terminal swellings forms a characteristic "nid" on the soma of a Purkinje cell. Marker $=10 \mu \mathrm{m}$.

are here termed "combination" axons. The most common form of combination axon is a fiber of large diameter that projects diagonally through the granule layer, having one to three mossy fiber terminals along its length. The most distal swellings are usually less mature in shape and bear many short (approximately 10 to $20 \mu \mathrm{m}$ ) filopodia. In addition, one to two long filopodial extensions (up to $100 \mu \mathrm{m}$ ) extend into the Purkinje cell layer and give rise to small foliate en passant and terminal expansions of the sort seen on climbing fibers. The filopodial branches curve around individual Purkinje cell somata and cross over as many as six Purkinje somata, issuing small swellings to each cell. At the light microscope level, single Purkinje cells appear to receive such filopodial branches from more than one mossy fiber-like combination axon. Combination mossy fibers, that is, axons with primarily mossy fiber-like characteristics proximally and terminal climbing fiber-like branches within the Purkinje cell layer, are more common than combination climbing fibers, whose arbors are mainly climbing fiber-like within the Purkinje cell layer, and issue short collaterals with mossy terminals into the granule cell layer (Fig. 10a).

When analyzed in the electron microscope, the mossy fiber-like boutons of fibers that show primarily mossy fiber morphology proximally and climbing fiber morphology distally make characteristic glomeruli with granule cell dendrites (Fig. 12a). The fine filopodial branches make elementary contacts onto both Purkinje cells and granule cells (Fig. 13). The types of contacts include adherent junctions onto somatic spines of Purkinje cells (Fig. 13d) and onto shafts of growth cones within the neuropil (Fig. 12b). Other contacts made by the fine branches are elementary synaptic contacts onto Purkinje cell somata, with an accumulation of a few vesicles but no density (Fig. 13, $a$ and $b$ ). In Figure $13 d$, an unlabeled profile (marked $x$ ) is adjacent to the labeled filopodial branch of a combination mossy fiber. In earlier studies (e.g., Laramendi, 1969), this type of profile would have been identified as deriving from climbing fibers, but since the cytology of this and the labeled profile from the combination mossy axon are similar, its identity is in question. Contacts with accumulation of a few vesicles and both pre- and postsynaptic densities are made by fine branches of combination mossy fibers onto Purkinje cell somatic spines (Fig. 13c), onto unidentified profiles (Fig. 13e), as well as onto granule cells (Fig. 13f). Some fine branches make contacts onto granule cells that descend through the line of Purkinje cells (not shown).

Two features of combination fibers should be emphasized. First, the fine branches of combination mossy fibers that extend into the Purkinje cell layer never project further than the apical tip of the Purkinje cell soma. In contrast, combination climbing fibers, with short mossy fiber-like collaterals, extend into the molecular layer as typical climbing fiber arbors (Fig. 10a). 

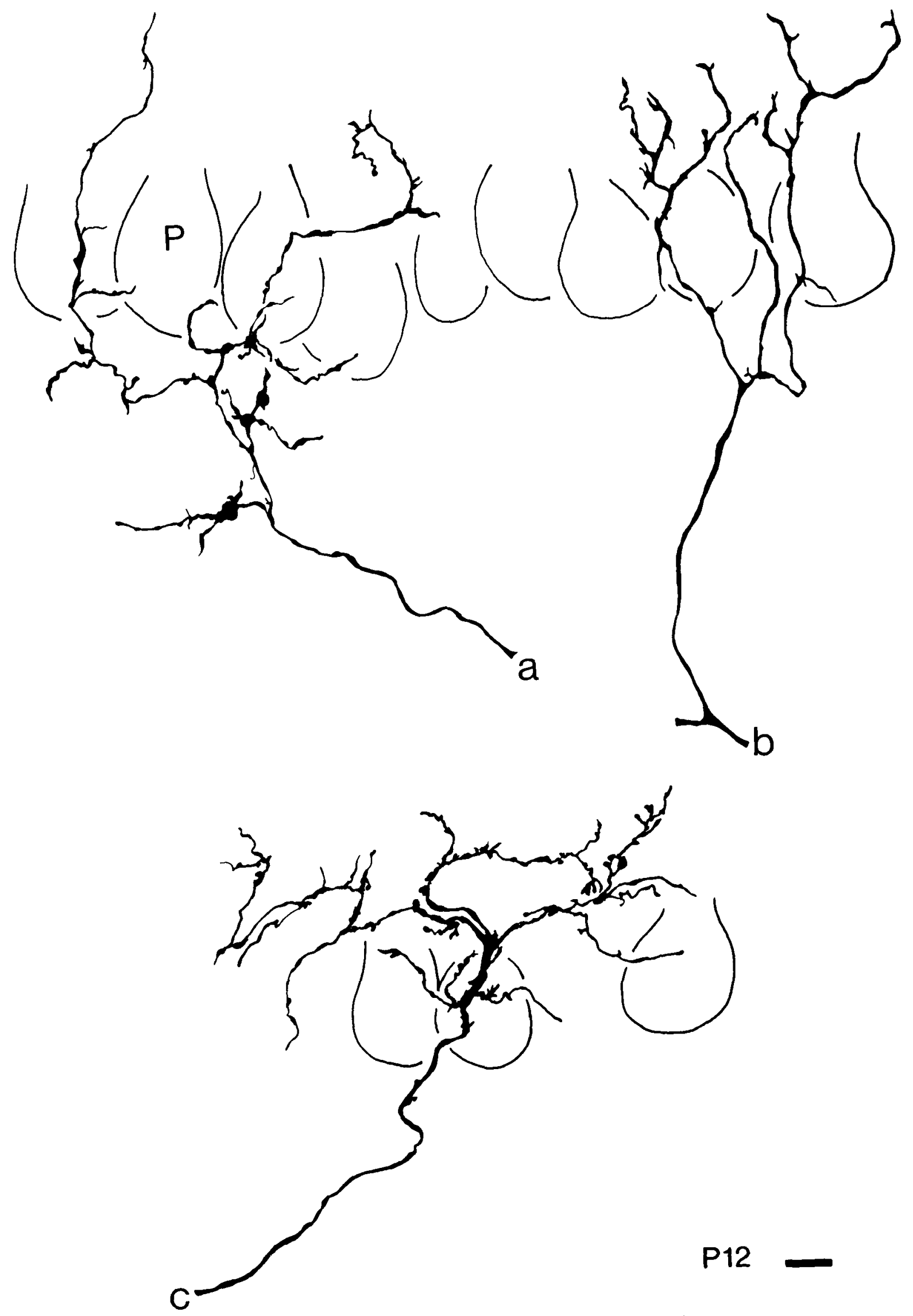

Figure 10. Characteristic climbing fiber arbors at P12. Terminal swellings on axon $c$ are more distinct and adult-like than those on axons $a$ or $b$. Note that axon $a$ also gives rise to a mossy fiber-like swelling in the granule layer, making it a combination climbing fiber. All axons appear to extend over more than one Purkinje cell. Marker $=10 \mu \mathrm{m}$. 


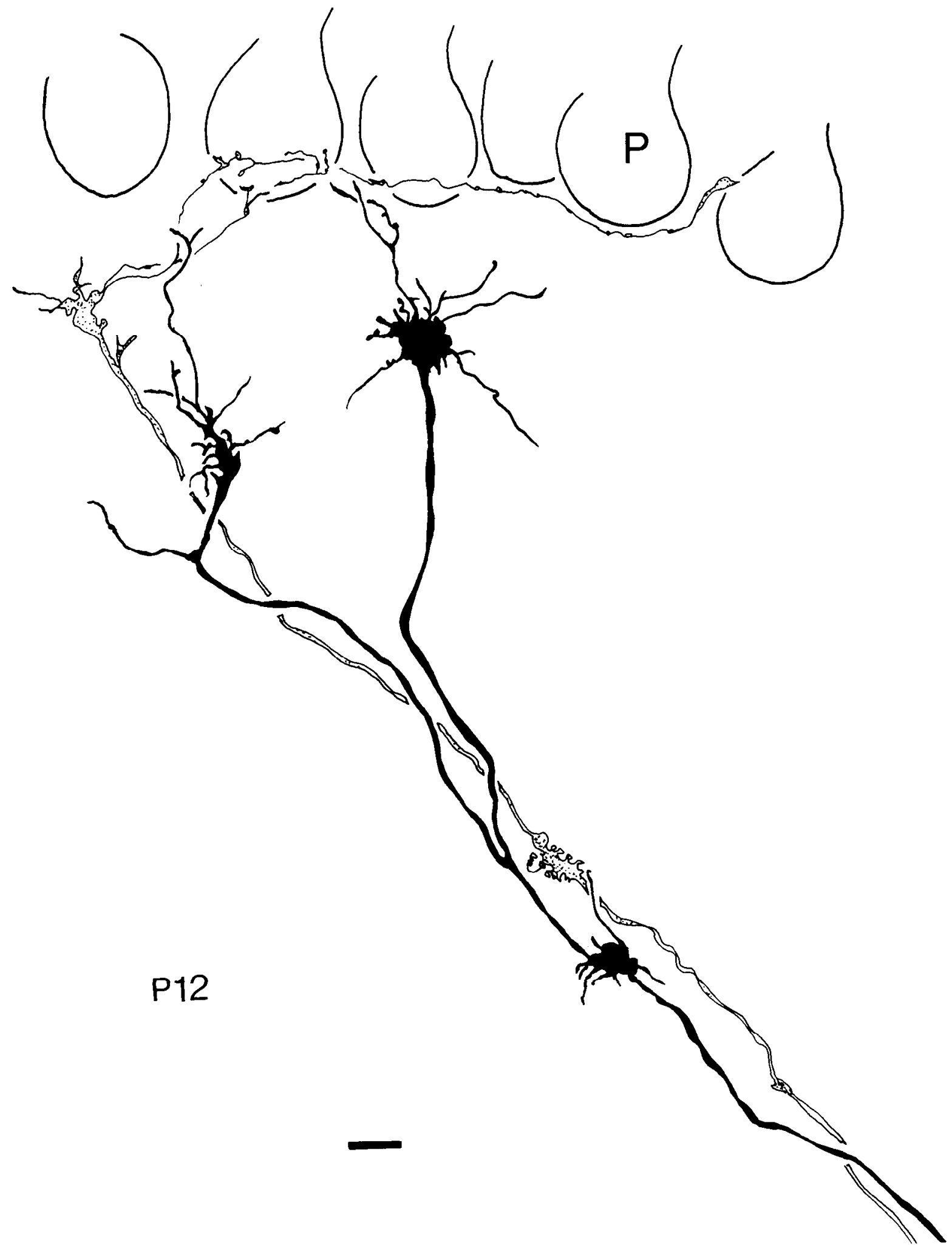

Figure 11. Combination mossy fibers at P12 that are mossy fiber-like in the granule layer and also give rise to delicate filopodial branches with climbing fiber-like terminals that extend into the Purkinje cell layer, usually over more than one Purkinje cell $(P)$. Marker $=10 \mu \mathrm{m}$.

Second, the contacts made by the branches of combination mossy fibers that project into the Purkinje cell layer appear to be primitive, i.e., consisting of puncta adhaerentia, or accumulations of a few vesicles, with or without a short density. Regardless of whether these structures are indications of incipient synaptic specializations or simply attachment points (see McGraw and McLaughlin, 1980 for discussion), we speculate that they represent 

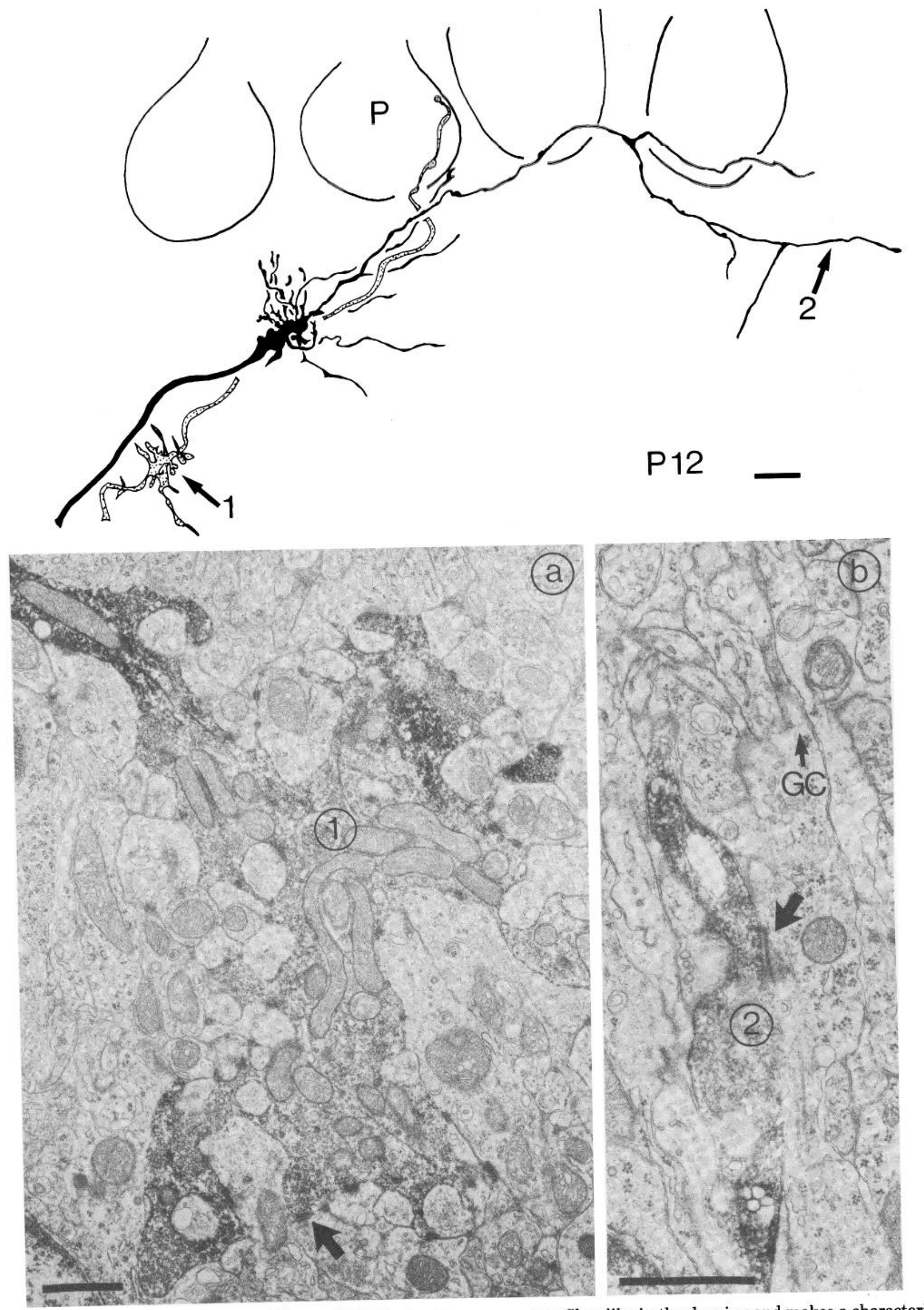

Figure 12. Two combination mossy fibers at P12. Bouton 1 appears mossy fiber-like in the drawing and makes a characteristic synaptic glomerulus (micrograph a). The filopodial branch arising from a combination mossy fiber at point 2 makes an adherent junction (arrow) with an unlabeled growth cone $(G C)$. The filopodium of that growth cone is shown by the small arrow. (Micrograph $b$ has been rotated $90^{\circ}$ with respect to the drawing.) Marker in drawing $=10 \mu \mathrm{m} ;$ marker in micrograph $=1 \mu \mathrm{m}$. 

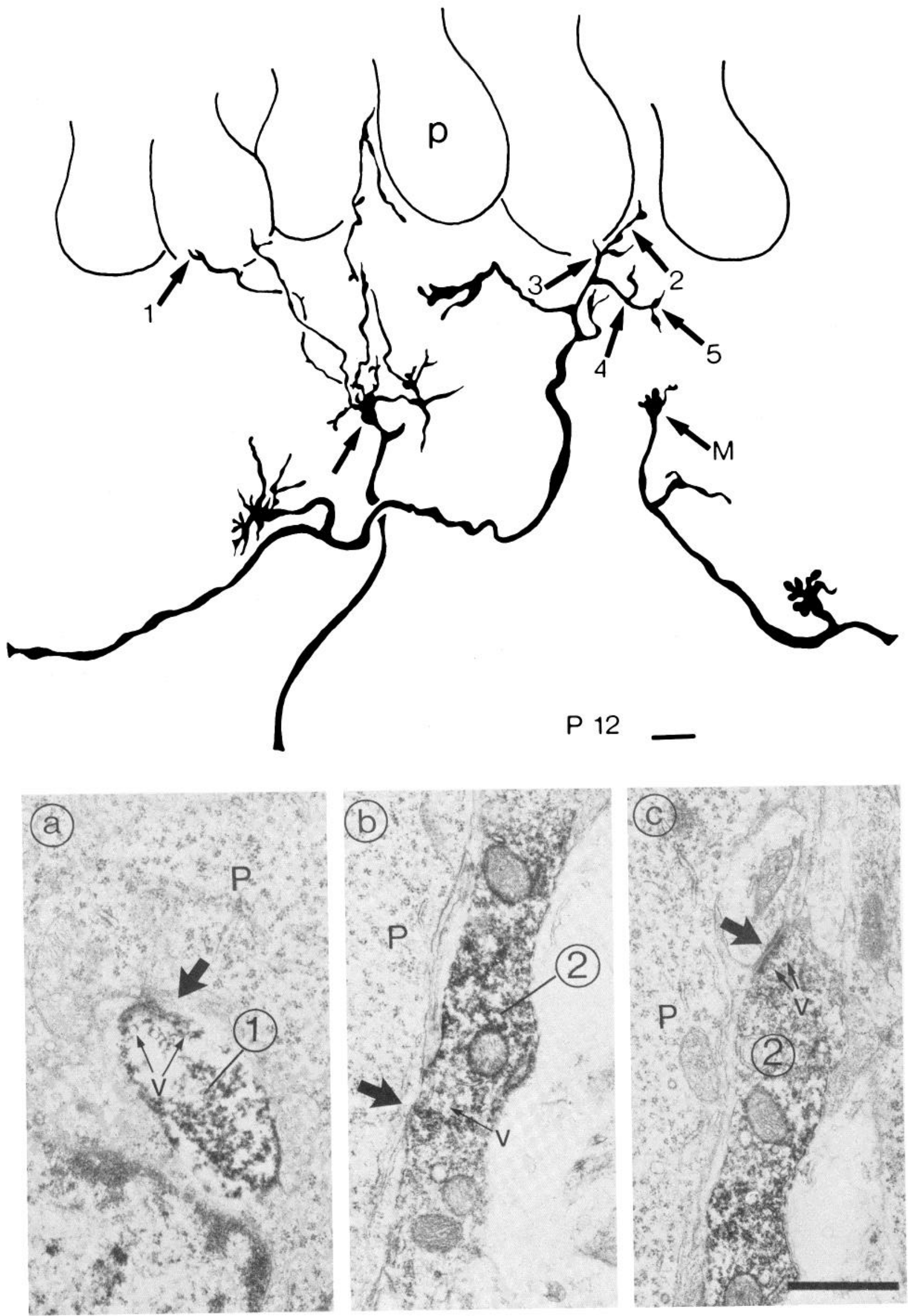

Figure 13, a to c 

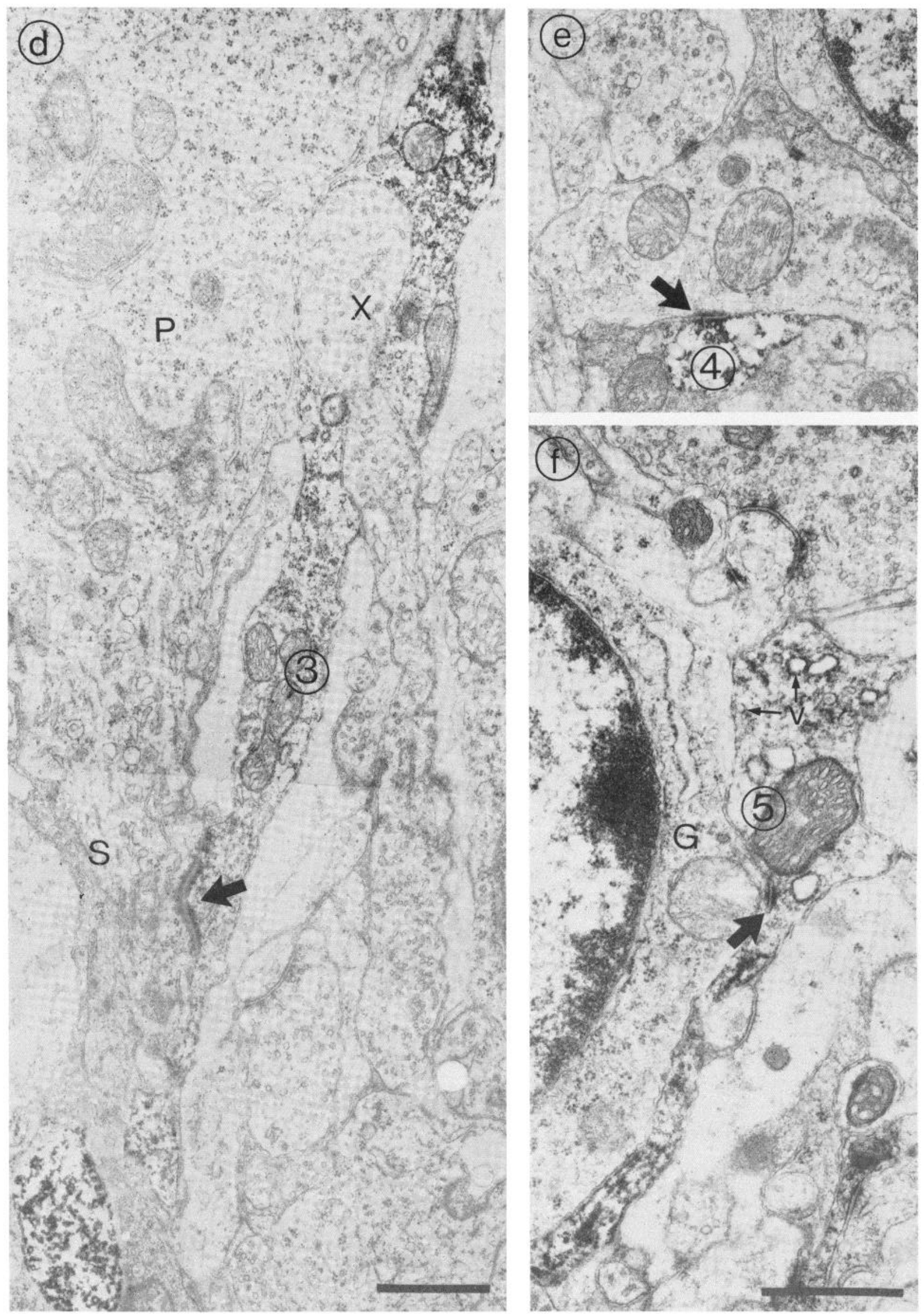

Figure 13, $d$ to $f$ 
the trial and error steps accompanying the formation of specific contacts by other more appropriate portions of the axon.

By P21, combination fibers consist largely of mossy fiber lengths with shorter projections toward Purkinje cells. By P30 and into adulthood, combination climbing fibers with mossy terminals in the granule layer are rare, and combination mossy fibers were not observed.

\section{Discussion}

We have found that although the afferent axons of the cerebellum are already present in the cerebellar anlage at the time of birth, they do not develop their characteristic features until the end of the first postnatal week. Furthermore, when characteristic morphology becomes obvious, many single axons transiently express the phenotypes (terminal shapes and synaptic connections) of both types of afferent axon. We will consider the second finding in light of the first.

Waiting axons and the development of combination fibers. In some cortical systems, afferents apparently "wait" in subcortical zones before invading target regions, but the rules of synaptic connections of waiting axons have not been delineated in any of the systems in which this phenomenon occurs (Rakic and Sidman, 1970; Lund and Mustari, 1977; Wise et al, 1979). In the cerebellum, many of the cells which project as climbing and mossy fibers are born (in rat) from E13 to E19 (Altman and Bayer, 1978). Afferent axons (in mouse) arrive in the cerebellar anlage as early as 6 days prenatal (Tello, 1940; Sidman, 1968; C. A. Mason and R. Liem, manuscript in preparation) and appear to overlap in their projection, both during late embryonic stages, when they fill the cerebellar anlage up to the external granule layer, and in early postnatal periods, when they lie in a plexus beneath the newly formed Purkinje cell layer (in human cerebellum, referred to as the lamina dissecans, Rakic and Sidman, 1970). Growing tips on cerebellar axons during this period are similar despite the fact that afferent axons derive from different brainstem sources. Characteristic terminal structures do not develop until over a week later, but this does not necessarily signify the absence of early contacts with target cells, even though the cells have not yet developed their dendrites (Ramón y Cajal, 1911, 1960; Altman, 1972; Rakic, 1975). Such waiting immature axons may contact cells in a primitive form, either by elementary synaptic, adherent, or even electrotonic junctions (Ginzberg and Gilula, 1980; Tagh- ert et al., 1982). However, connectivity studies need to be performed to confirm that axons from both climbing and mossy fiber sources have already projected to cerebellum at the time the unclassifiable axons are seen.

Three possibilities exist for the transient expression of both mossy and climbing fiber branching patterns and bouton shape on the same fiber. First, waiting axons that are future mossy fibers might temporarily contact Purkinje cells, since these cells are dispersed in the embryonic cerebellar anlage and the normal target granule cells of mossy fibers have not yet migrated inward from the external granule layer. Mossy fibers that overlapped in their projection with climbing fibers in embryonic stages would remain in contact with inappropriate target Purkinje cells as these cells migrate into position. Mossy fibers would then develop climbing fiber-like boutons onto Purkinje cells as well as mossy boutons onto appropriate target granule cells, thus becoming combination axons. It is possible that this hypothesis could explain the "heterologous" synapses made by mossy fibers onto Purkinje cells in cerebella rendered agranular either from such neurological mutations as weaver or upon $\mathrm{x}$-irradiation (for review, see Sotelo, 1982), thus reflecting the persistence of inappropriate branches of combination axons.

A second possibility is that filopodia that arise from combination mossy fibers contact inappropriate cells during exploratory movements in postnatal periods. Mossy fibers may also extend filopodia toward the direction of migrating granule cells as they descend and contact nearby Purkinje cells at the same time. More data are needed on whether axons contact cells soon after their arrival in the cerebellum, the nature of these contacts (see Llinás and Sugimori, 1979), the identity of the contacted cells, and the extent of the projection of both climbing and mossy fibers before the formation of the Purkinje cell layer.

Characterization of the electrophysiology of combination axons would also clarify their synaptic relations. It is possible that in the determination of supernumerary climbing fiber input onto immature Purkinje cells in rat cerebellum (Crepel et al., 1976; Mariani and Changeux, 1981; Crepel, 1982), the graded action potentials that were observed derived not only from redundant climbing fiber branches but also from the supernumerary filopodial branches projected by combination mossy fibers.

The shape and cytology of growing tips. The postnatal development of mossy and climbing fibers has been doc-

Figure 13. Two combination fibers and a mossy fiber at P12 and selected electron micrographs of identified portions (1 to 5 ) of these HRP-labeled fibers. a, A claw-like swelling (1) at the end of a filopodial branch arising from a mossy terminal (arrow) contains an accumulation of clear vesicles $(v)$ where it contacts a Purkinje cell soma $(P)$. A synaptic density was not observed in this or other adjacent sections, but the membrane of the Purkinje cell appears ruffled. $b$, In growing tip 2 , an accumulation of vesicles $(v)$ occurs where the labeled profile is adjacent to the Purkinje cell membrane (arrow), even though a membrane specialization is lacking (compare to $a$ ). $c$, In another section through this branchlet (micrograph c), growing tip 2 makes an elementary synaptic contact, consisting of pre- and postsynaptic densities (arrow) and a few vesicles $(v)$, with a profile that was seen in other sections to be continuous with the Purkinje cell soma $(P)$. $d$, The lower portion of growing tip 2 makes a long adherent contact (arrow) with a perikaryal spine $(s)$ of the same Purkinje cell contacted by other parts of 2 . Note the unlabeled vesicle-containing profile $(X)$ that abuts the soma. It resembles part 2 as well as presumed climbing fiber terminals in unlabeled material, as described by Larramendi (1969). e, Small labeled swelling (4) makes an elementary synaptic contact (arrow), consisting of a cluster of a few vesicles and a short pre- and postsynaptic density, with an unidentified profile. $f$, A growing tip (5) with large clear vesicles $(v)$ makes a contact (arrow), similar to the one in $d$, with a granule cell soma ( $G$ ). (The micrograph has been rotated $90^{\circ}$ with respect to the drawing.) Marker in drawing $=10 \mu \mathrm{m}$; marker in micrographs $=1 \mu \mathrm{m}$. 
umented at the light microscopic level (Athias, 1897; Ramón y Cajal, 1911; 1960; O'Leary et al., 1971; Palay and Chan-Palay, 1974) and at the ultrastructural level (e.g., Larramendi, 1969; Mugnaini, 1969; Hámori and Somogyi, 1983; Landis et al., 1983), but the images from the two kinds of observations have rarely been correlated. From light microscopic observations, Athias (1897) considered the expansions with filopodia on mossy fibers to be growth cones. Ramón y Cajal (1911) recognized that mossy terminals were smooth in their more primitive state and that they only later emitted short thin projections. In our study, we have shown that during the waiting period, structures that resemble growth cones in the light microscope do not make obvious synaptic contacts. By the end of the first postnatal week, however, large growth cone-like structures are associated with synaptic formations, in this case, recognizable elementary glomeruli. In contrast, filopodia on both climbing and mossy fiber-like axons during this time engage in elementary contacts, in the form of endocytotic figures, simple accumulation of vesicles, or adherent contacts. The synaptic relations of immature mossy fiber terminals in this way resemble those of developing retinogeniculate terminals in the kitten, in which the base of growth cone-like structures is the central profile in a glomerulus (Hámori and Somogyi, 1983; Landis et al., 1983), while the more slender extensions form simpler contacts (Mason, 1982a, b). Since the growth cones and growing tips on waiting cerebellar axons are much smaller than adult mossy terminals, expansion of growing tips and subsequent outgrowth of filopodia must accompany establishment of synaptic arrangements. Therefore, the form of the expansion resembles growth cones seen in vitro (Johnston and Wessells, 1980; Letourneau, 1982) long after outgrowth has taken place.

A variety of forms of axonal tips has been seen both in vitro (Johnston and Wessells, 1980) and in vivo (Ramón y Cajal, 1911; Speidel, 1942; Roberts, 1976), from blunt ends to a broad foot bearing filopodia. However, the relationship of these forms to temporal and spatial positions along pathways or within targets is obscure. It is also unclear to what extent forms and cytology of growth cones in culture relate to those in vivo (e.g., del Cerro and Snider, 1968; Tennyson, 1970; Bunge, 1973; Vaughn et al., 1974; Nordlander and Singer, 1982). What is evident from in vitro studies is that growth cones vary in shape according to their adhesivity to different surfaces (Letourneau, 1982). Although in vitro experiments have focused on axonal outgrowth, differential adhesivity of growing tips on appropriate cell surfaces may in part account for modification of shape from bud-like growing tips on neonatal axons to the expanded growth cone-like structures on mossy fibers during postnatal maturation, as their proper target granule cells become available.

Relationship of terminal bouton shape to target cell features. Axons express their features as mossy fiber-like or climbing fiber-like, depending on whether they project into granule or Purkinje cell layers, respectively. Mossy fiber-like terminals are never found in the Purkinje cell layer of normal postnatal mice. The shape of terminal swelling on individual fibers also reflects their synaptic relationships. Knobby mossy fiber-like terminals always form the central profile in a glomerulus and synapse with granule cell dendrites, whereas small round climbing fiber-like terminals form axodendritic synapses on spines of Purkinje cells (Palay and Chan-Palay, 1974). Even though some immature fibers transiently project into both granule and Purkinje cell layers, the shape of terminals on each branch corresponds to the target cell type, supporting the notion that the shape of the presynaptic terminal is determined by interactions of growing tips with the target cell surface (Morest, 1968, 1969a, b; Mugnaini, 1970; Hámori, 1973; Rakic, 1975).

The forms of climbing and mossy fiber-like synaptic boutons can be interpreted in more general terms, similar to those observed in retinogeniculate axons (Mason and Robson, 1979; Robson and Mason, 1979). Large oblong retinal terminals with an indented surface are the central profile in a synaptic glomerulus, in which several other dendrites are contacted by one terminal. The surface of retinogeniculate terminals is indented by apposing grapelike dendritic appendages of postsynaptic cells (Robson and Mason, 1979; Mason et al., 1983), whereas mossy terminals are lobulated, possibly because a claw-like granule cell dendrite encloses each lobe. Climbing fiberlike terminals, like the smaller terminals of retinogeniculate axons, are slightly indented and make simple axodendritic or axospinous contacts, usually with one synaptic contact per bouton. A single retinogeniculate axon in the adult cat can bear both kinds of terminals and, thus, make at least two kinds of synaptic connections (Robson and Mason, 1979). Therefore, the finding that single cerebellar axons also make two kinds of contacts is not inherently surprising. The apparent difference between retinogeniculate and cerebellar afferents is that mossy and climbing fibers in the mature cerebellum usually do not overlap extensively in their projections and synaptic connections, although collaterals of climbing fibers issued into the granule layer have been reported to give rise to mossy terminals (Scheibel and Scheibel, 1954; Palay and Chan-Palay, 1974).

Exuberance and sorting out. We have observed three types of exuberance in developing cerebellar axons: (1) Purkinje cells receive branches from more than one axon, either from pure climbing fibers or mossy combination fibers with climbing fiber-like branches; (2) individual climbing fibers or mossy combination fibers contact more than one adjacent Purkinje cell; (3) individual combination fibers project into both granule and Purkinje cell layers and synapse with both granule and Purkinje cells. Most of these types of exuberance are transient. An exception is that individual adult climbing fibers can project to different folia, thus synapsing with more than one, although widely separated, Purkinje cell (Fox et al., 1969; Brodal et al., 1980). With the HRP labeling technique it should be possible to relate these findings to the reported overbranching of immature climbing fibers demonstrated electrophysiologically (Crepel et al., 1976; Mariani and Changeux, 1981; Crepel, 1982) and to assess the numerical relationships of individual developing climbing and mossy fibers, as well as of combination fibers, with their target cells.

Examples of formation and subsequent pruning of axon branches have been documented in other systems, 
including callosal projections to visual cortex (Innocenti, 1981; Ivy and Killackey, 1981), retinal axons (Rakic and Riley, 1983), the superior cervical ganglion (Lichtman and Purves, 1980), and neuromuscular junction (Van Essen, 1982). These diffuse projections are presumed to represent superfluous numbers of afferents onto matched or correct target cells (see Clarke, 1981 for review). Since the circuitry of the cerebellum is far better understood than any other region in CNS, and target cell types are easily identifiable by ultrastructural criteria, the exuberance with regard to the form and projection as well as dual synaptic connections of combination fibers during postnatal development is more readily detected. Ramón y Cajal (1960) noted that branches of some immature mossy fibers ascend into the Purkinje cell layer, but this observation was made without fully understanding the identity of mossy fibers and without the benefit of the electron microscope. However, it is conceivable that there are some axons which always make connections with several cell types even into adulthood. Thus, axons with dual morphology should not be considered "mistakes" during development (Clarke, 1981) but perhaps as necessary phases of maturation.

The ultimate signal and the mechanism for sorting out, either with respect to numbers, to recognition of correct target cell types, or as in the case of retinal afferents to the lateral geniculate nucleus, with respect to segregation of afferents into layers (Rakic, 1977; Shatz, 1983), is not yet known. It is possible that granule and Purkinje cells at first share common surface molecules that lure axons or are permissive for movement on them and replace those with other molecules that would induce differential adhesivity and subsequent shape changes in growing tips. These molecules might include antigens for Purkinje cell-specific antigen markers or carbohydrate-containing macromolecules bound by lectins (Hatten and Sidman, 1978; Edelman and Chuong, 1982). If exuberant branches, especially those derived from combination mossy axons that project onto Purkinje cells, represent a final stage in the searching, trial synapsing, and subsequent sorting out of axons (Steinberg, 1970; Changeux and Danchin, 1976; Ruffolo et al., 1978), then it will be important to correlate maturational changes of axonal forms with the expression of cellular and extracellular molecules.

\section{References}

Altman, J. (1971) Coated vesicles and synaptogenesis. A developmental study in the cerebellar cortex of the rat. Brain Res. 30: 311-322.

Altman, J. (1972) Postnatal development of the cerebellar cortex in the rat. II. Phases in the maturation of Purkinje cells and of the molecular layer. J. Comp. Neurol. 145: 399464.

Altman, J., and S. A. Bayer (1978) Prenatal development of the cerebellar system in the rat. II. Cytogenesis and histogenesis of the inferior olive, pontine gray and the precerebellar reticular nuclei. J. Comp. Neurol. 179: 49-76.

Amaral, D. G., and J. A. Dent (1981) Development of the mossy fibers of the dentate gyrus. I. A light and electron microscopic study of the mossy fibers and their expansions. J. Comp. Neurol. 195: 51-86.

Athias, M. (1897) Recherches sur l'histogenese de l'ecorce du cervelet. J. Anat. Physiol. Norm. Pathol. Homme Anim. 33: 372-399.

Brodal, A., F. Walberg, K. J. Berkley, and A. Pelt (1980) Anatomical demonstration of branching olivo-cerebellar fibera by meane of a double retrograde labolliniz technique. Neuroscience 5: 2193-2202.

Bunge, M. B. (1973) Fine structure of nerve fibers and growth cones of isolated sympathetic neurons in culture. J. Cell Biol. 56: 713-735.

Changeux, J. -P., and A. Danchin (1976) Selective stabilization of developing synapses as a mechanism for the specification of neuronal networks. Nature 264: 705-711.

Clarke, P. G. H. (1981) Chance, repetition, and error in the development of normal nervous systems. Perspect. Biol. Med. 25: 2-19.

Crepel, F. (1982) Regression of functional synapses in the immature mammalian cerebellum. Trends. Neurosci. 5: 266269.

Crepel, F., J. Mariani, and N. Delhaye-Bouchaud (1976) Evidence for a multiple innervation of Purkinje cells by climbing fibers in the immature rat cerebellum. J. Neurobiol. 7: 567578.

del Cerro, M. P., and R. S. Snider (1968) Studies on the developing cerebellum. Ultrastructure of the growth cones. J. Comp. Neurol. 133: 341-362.

Eckenhoff, M. F., and J. J. Pysh (1979) Double-walled coated vesicle formation-Evidence for massive and trañisient coñjugate internalization of plasma membranes during cerebellar development. J. Neurocytol. 8: 623-638.

Edelman, G. M., and C. -M. Chuong (1982) Embryonic to adult conversion of neural cell adhesion molecules in normal and staggerer mice. Proc. Natl. Acad. Sci. U. S. A. 79: 7036-7040.

Fox, C. A., A. Andrade, and R. C. Schwyn (1969) Climbing fiber branching in the granular layer. In Neurobiology of Cerebellar Evolution and Development, R. Llinás, ed., pp. 603-611, American Medical Association/Education and Research Foundation Institute of Biomedical Research, Chicago.

Ginzberg, R. D., and N. B. Gilula (1980) Synaptogenesis in the vestibular sensory epithelium of the chick embryo. J. Neurocytol. 9: 405-424.

Hámori, J. (1973) 'The inductive role of presynaptic axons in the development of postsynaptic spines. Brain Res. 62 : $337-$ 344.

Hámori, J., and J. Somogyi (1983) Differentiation of cerebellar mossy fiber synapses in the rat: A quantitative electron microscope study. J. Comp. Neurol. 220: 365-377.

Harrison, R. G. (1910) The outgrowth of the nerve fiber as a mode of protoplasmic movement. J. Exp. Zool. 9: 787-846.

Hatten, M. E., and R. L. Sidman (1978) Cell association behavior and lectin-induced agglutination of embryonic mouse cells from different brain regions. Exp. Cell Res. 113: 111125.

Innocenti, G. M. (1981) Growth and reshaping of axons in the establishment of visual callosal connections. Science 212: $824-826$.

Ivy, G. O., and H. P. Killackey (1981) The ontogeny of the distribution of callosal projection neurons in the rat parietal cortex. J. Comp. Neurol. 195: 367-389.

Jhaveri, S., and D. K. Morest (1982) Sequential alterations of neuronal architecture in nucleus magnocellularis of the developing chicken: A Golgi study. Neuroscience 7: 837-853.

Johnston, R. N., and N. K. Wessells (1980) Regulation of the elongating nerve fiber. Curr. Top. Dev. Biol. 16: 165-252.

Keshishian, H., and D. Bentley (1983) Embryogenesis of peripheral nerve pathways in grasshopper legs. I. The initial pathway to the CNS. Dev. Biol. 96: 89-102.

Landis, D. M. D., L. Weinstein, and J. J. Halperin (1983) Development of synaptic junctions in cerebellar glomeruli. 
Dev. Brain Res. 8: 231-245.

Larramendi, L. M. H. (1969) Analysis of synaptogenesis in the cerebellum of the mouse. In Neurobiology of Cerebellar Evolution and Development, R. Llinâs, ed., pp. 803-843, American Medical Association/Education and Research Foundation Institute of Biomedical Research, Chicago.

Lêtourneau, P. C. (1982) Nerve fiber growth and its regulation by extrinsic factors. In Neural Development, N. C. Spitzer, ed., pp. 213-254, Plenum Press, New York.

Lichtman, J. W., and D. Purves (1980) The elimination of redundant preganglionic innervation to hamster sympathetic ganglion cells in early postnatal life. J. Physiol (Lond.) 301: $213-228$.

Llinás, R., and M. Sugimori (1979) Calcium conductances in Purkinje cell dendrites: Their role in development and integration. Prog. Brain Res. 51: 323-334.

Lund, R. D., and M. J. Mustari (1977) Development of geniculocortical pathway in rats. J. Comp. Neurol. 173: 289-305.

Mariani, J., and J. -P. Changeux (1981) Ontogenesis of olivocerebellar relationships. I. Studies by intracellular recordings of the multiple innervation of Purkinje cells by climbing fibers in the developing rat cerebellum. J. Neurosci. 1: 696702.

Mason, C. A. (1982a) Development of terminal arbors of retinogeniculate axons in the kitten. I. Light microscopical observations. Neurossciencèce 7: 541-560.

Mason, C. A. (1982b) Development of terminal arbors of retinogeniculate axons in the kitten. II. Electron microscopical observations. Neuroscience 7: 561-582.

Mason, C. A., and J. A. Robson (1979) Morphology of retinogeniculate axons in the rat. Neuroscience 4: 79-98.

Mason, C. A., R. W. Guillery, and M. C. Rosner (1983) Patterns of synaptic contact upon individually labeled large cells of the dorsal lateral geniculate nucleus of the cat. Neuroscience 11: $319-329$.

McGraw, C. F., and B. J. McLaughlin (1980) Fine structural studies of synaptogenesis in the superficial layers of the chick optic tectum. J. Neurocytol. 9: 79-93.

Morest, D. K. (1968) The growth of synaptic endings in the mammalian brain: A study of the calyces of the trapezoid body. Z. Anat. Entwicklungsgesch. 127: 201-220.

Morest, D. K. (1969a) The differentiation of cerebral dendrites: A study of the post-migratory neuroblast in the medial nucleus of the trapezoid body. Z. Anat. Entwicklungsgesch. 128: 271-289.

Morest, D. K. (1969b) The growth of dendrites in the mammalian brain. Z. Anat. Entwicklungsgesch. 128: 290-317.

Mugnaini, E. (1969) Ultrastructural studies on the cerebellar histogenesis II. Maturation of nerve cell populations and establishment of synaptic connections in the cerebellar cortex of the chick. In Neurobiology of Cerebellar Evolution and Development, R. Llinás, ed., pp. 749-782, American Medical Association/Education and Research Foundation Institute of Biomedial Research, Chicago.

Mugnaini, E. (1970) Neurons as synaptic targets. In Excitatory Synaptic Mechanisms, P. Anderson and J. K. S. Jansen, eds., pp. 149-169, Universitesvorlaget, Oslo.

Nordlander, R. H., and M. Singer (1982) Morphology and position of growth cones in the developing Xenopus spinal cord. Dev. Brain Res. 4: 181-193.

O'Leary, J., J. Inukai, and J. M. Smith (1971) Histogenesis of the climbing fiber in the rat. J. Comp. Neurol. 142: 377-392.

Palay, S. L., and V. Chan-Palay (1974) Cerebellar Cortex, Springer-Verlag, New York.

Purves, D., and J. W. Lichtman (1980) Elimination of synapses in the developing nervous system. Science 210: 153-157.

Rakic, P. (1975) Role of cell interaction in development of dendritic patterns. Adv. Neurol. 12: 117-134.

Rakic, P. (1977) Prenatal development of the visual system on the rhesus monkey. Philos. Trans. R. Soc. Lond. Biol. 278: $245-260$.

Rakic, P., and K. P. Riley (1983) Overproduction and elimination of retinal axons in the fetal rhesus monkey. Science 219: 144143 .

Rakic, P., and R. L. Sidman (1970) Histogenesis of cortical layers in human cerebellum, particularly the lamina dissecans. J. Comp. Neurol. 139: 473-500.

Ramón y Cajal, S. (1911) Histologie du Système Nerveux de l'Homme et des Vertébrés, Vols. I and II, Maloine, Paris.

Ramón y Cajal, S. (1960) Studies on Vertebrate Neurogenesis, Charles C Thomas, Springfield, IL.

Raper, J. A., M. Bastiani, and C. S. Goodman (1983) Pathfinding hy neuronal growth cones in grasshopper embryos. I. Divergent choices made by the growth cones of sibling neurons. J. Neurosci. 3: 20-30.

Roberts, A. (1976) Neuronal growth cones in an amphibian embryo. Brain Res. 118: 526-530.

Robson, J. A., and C. A. Mason (1979) The synaptic organization of terminals traced from individual labeled retino-geniculate axons in the cat. Neuroscience 4: 99-112.

Ruffolu, R. R., Jr., G. S. Eisenbarth, J. M. Thompson, and M. Nirenberg (1978) Synapse turnover: A mechanismin for acquiriñg synaptic specificity. Proc. Natl. Acad. Sci. U. S. A. 75: $2281-2285$.

Scheibel, M. W., and A. B. Scheibel (1954) Observations on the intracortical relations of the climbing fibers of the cerebellum. J. Comp. Neurol. 101: 733-63.

Shatz, C. J. (1983) The prenatal development of the cat's retinogeniculate pathway. J. Neurosci. 3: 482-499.

Sidman, R. L. (1968) Development of interneuronal connections in the brains of mutant mice. In Physiological and Biochemical Aspects of Nervous Integration, F. D. Carlson, ed.. pp. 163-193, Prentice-Hall, Englewood Cliffs, NJ.

Sotelo, C. (1982) Synaptic remodeling in agranular cerebellum. In The Cerebellum-New Vistas, S. L. Palay and V. ChanPalay, eds., pp. 50-68, Springer-Verlag, New York.

Speidel, C. C. (1942) Studies of living nerves. VII. Growth adjustments of cutaneous terminal arborizations. J. Comp. Neurol. 76: 57-69.

Steinberg, M. S. (1970) Does differential adhesion govern selfassembly processes in histogenesis? Equilibrium configurations and the emergence of a hierarchy among populations of embryonic cells. J. Exp. Zool. 173: 395-434.

Taghert, P. H., M. J. Bastiani, R. K. Ho, and C. S. Goodman (1982) Guidance of pioneer growth cones: Filopodial contacts and coupling revealed with an antibody to Lucifer Yellow. Dev. Biol. 94: 391-399.

Tello, J. F. (1940) Histogenese du cervelet et ses voies chez la souris blanche. Trabajos Inst. Cajal Invest. Biol. 32: 1-72.

Tennyson, V. (1970) The fine structure of the axon and growth cone of the dorsal root neuroblast of the rabbit embryo. J. Cell Biol. 44: 62-79.

Van Essen, D. C. (1982) Neuromuscular synapse elimination. In Neuronal Development, N. C. Spitzer, ed., pp. 333-376, Plenum Press, New York.

Vaughn, J. E., C. K. Henrikson, and J. A. Grieshaber (1974) A quantitative study of synapses on motor neuron dendritic growth cones in developing mouse spinal cord. J. Cell Biol. 60: 664-672.

Wise, S. P., J. W. Fleshman, Jr., and E. G. Jones (1979) Maturation of pyramidal cell form in relation to developing afferent and efferent connections of rat somatic sensory cortex. Neuroscience 4: 1275-97. 